\title{
The polygenetic caves of Cuatro Ciénegas (Coahuila, Mexico):
}

\section{morphology and speleogenesis}

\author{
Leonardo Piccini ${ }^{1,2}$, Paolo Forti ${ }^{2,3}$, Italo Giulivo ${ }^{2}$, Marco Mecchia ${ }^{2}$
}

\begin{abstract}
:
Piccini L., Forti P., Giulivo I. and Mecchia M. 2007. The polygenetic caves of Cuatro Ciénegas (Coahuila, Mexico): Morphology and speleogenesis. International Journal of Speleology, 36 (2), 83-92. Bologna (Italy). ISSN $0392-6672$.

The Cuatro Ciénegas area is renown worldwide for its thermal springs, which feed a unique ecosystem consisting of many pools, lakes and marshes. The pools also represent a very important water resource in a region characterized by scarce rainfalls. Field investigation has emphasized the role of karst in the hydrogeology of the area. Only few and restricted forms of surface karst are represented; caves are mainly relics of old speleogenetic phases of thermal and bathyphreatic water flow.
\end{abstract}

Keywords: speleogenesis, hydrothermal karst, biogenic cave forms, Cuatro Ciénegas, Mexico.

Received 3 April 2007; Revised 14 May 2007; Accepted 21 May 2007

\section{INTRODUCTION}

The Cuatro Ciénegas plain, located in the Sierra Madre Oriental at the eastern edge of the Chihuahuan Desert, was designated a Natural Protected Area in 1994 to preserve its very peculiar flora and fauna. Although it receives little rain, the plain has abundant subterranean water, which rises in a wide area to form hundreds of pools (locally called pozas), marshes, rivers, lakes (large, temporary saline lakes locally called lagunas or playas), and canals with a unique biota of great interest to the international scientific community and which is at serious risk of extinction. Springs and surface water create a groundwaterdependent ecosystem characterized by a high level of endemism, which includes mainly fishes, amphibians, reptiles, snails, crustaceans, molluscs, insects and scorpions (Grall, 1995). A peculiar feature of the pools is the presence of living stromatolites, which serve as a primary part of the local food chain.

Understanding the mechanisms of water circulation is fundamental to the conservation of this important ecosystem (Johannesson et al., 2004). To achieve

1.Dipartimento di Scienze della Terra, Università di

Firenze, Via G. La Pira, 4 - I-50121 - Firenze (Italy), Tel: +39.0552757522, Fax: +39.055218628, e.mail: leonardo. piccini@unifi.it

2."La Venta" Geographical Association, Via Priamo Tron 35/F, Treviso (Italy).

3.Dipartimento di Scienze della Terra e Geologico-Ambientali, Bologna (Italy). this goal, the "La Venta" Geographical Association performed a study from 1999 to 2003 (Bernabei et al., 2002; Forti et al., 2003). This paper describes the geomorphic aspects of karst landforms and caves surveyed during the field investigation, which testify to an ancient bathyphreatic regional flow of thermal and meteoric waters, probably similar to that which feeds the present springs (Forti et al., 2004b).

\section{Geographical features}

\section{STUDY AREA}

The Sierra Madre Oriental crosses the state of Coahuila from $\mathrm{N}$ to $\mathrm{S}$, with a series of parallel mountain ridges, which enclose fluvio-lacustrine intermontane flats of different extension. The Cuatro Ciénegas plain is one of these flat areas. It extends over an area of about $840 \mathrm{~km}^{2}$ and is located at $27^{\circ} \mathrm{N}$ and $102^{\circ} \mathrm{W}$, at an altitude of about 700 metres. The high sloping walls of the Sierra Madera, which reach an altitude of $3020 \mathrm{~m}$ a.s.1., and the lower Sierra Menchaca, form the northern boundary of the area. The Sierra San Vincente and Sierra La Purisima border the plain on the eastern side. The southwestern boundary is the Sierra La Fragua, whereas the Sierra San Marcos y Pinos divides the Cuatro Ciénegas plain into two parts in its southern part (Fig. 1). All these mountains consist mainly of Cretaceous limestone folded into long asymmetric anticlines. Their more steep slopes, usually the southwestern sides, often show vertical or overturned beds. Steep slopes and vertical walls are deeply cut by longitudinal and transverse streams, which together form a typical "trellis" pattern. The northeast-facing slopes, many of which correspond to 


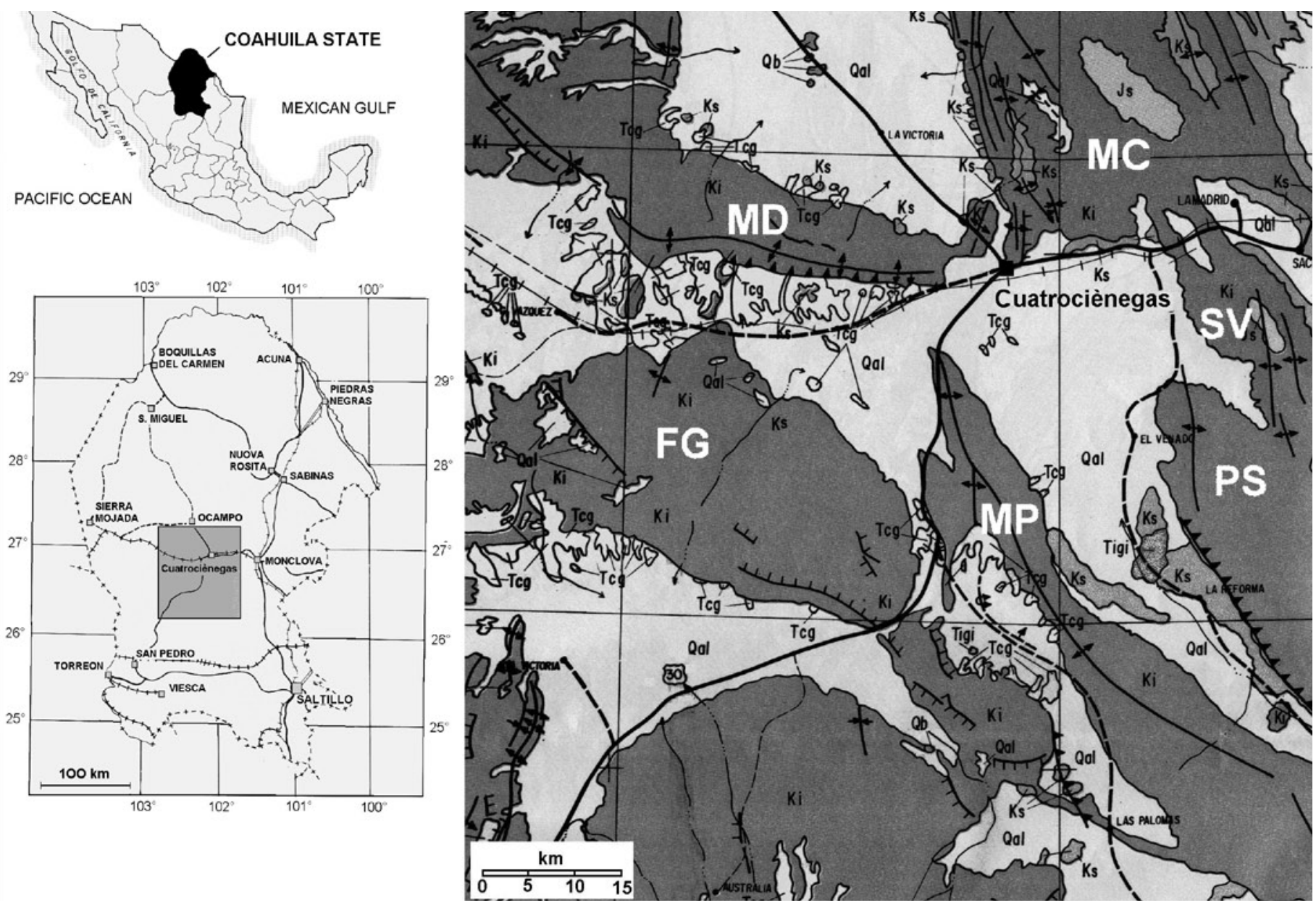

Fig. 1. Location and sketch geological map of Cuatro Ciénegas area: MD) Sierra Madera, MC) Sierra Menchaca, FG) Sierra La Fragua, MP) Sierra San Marcos y Pinos, SV) Sierra San Vincente, PS) Sierra La Purisima. Qal - Quaternary continental deposits, Qb - Quaternary vulcanites, Tcg - Tertiary conglomerate, Ks - Upper Cretaceous sandstone and limestone, Ki - Lower Cretaceous limestone, Js - Upper Jurassic limestone and evaporites, Tigi - Tertiary intrusive rocks. (From: Vargas et al., 1993).

the bedding surfaces of the limestone, are moderately steep and are widely incised by a complex network of streams that follows the dip of the beds. Some areas show an inversion of relief, where the anticlines have been deeply eroded due to the formation of longitudinal valleys, which indicates lengthy geomorphic evolution of the landscape (Fig. 2).

In the piedmont areas, the several coalescent fans, made up by detritus and fluvial deposits, form regular inclined surfaces (bajadas) marked by a discontinuous and mazy network, which testify to the intense mechanical erosion of slopes, despite the fact that streams are now active only during rare yet violent storms. Such drainage may thus represent former wetter climatic conditions (Meyer, 1973; Metcalfe et al., 1997, 2000).

In contrast, the central portion of the valley consists of endorheic "playas" typical of arid regions, mostly lacking water drainage, with wide flat basins. In scattered pools and marshes, sulphates are deposited as the result of strong evaporation (Forti et al., 2004a). Groundwater reaches the surface by flowing through evaporites and calcareous rocks, and finally rising into the pools with a large load of dissolved solids. Particles of gypsum are carried by wind and are deposited as dunes, which survive only because of the arid climate.

\section{Geologic and geomorphic framework}

In the study area a thick succession of Cretaceous limestone overlies continental mudstones and sandstones. Massive to medium thick beds of limestone crops out preferentially, and contains discontinuous beds of gypsum and marl. It is overlain by Paleogene mudstones and sandstones (Lehmann et al., 1998, 1999).

The present tectonic setting is the result of the Late Cretaceous to Tertiary "Laramide" deformation, which accounts for the formation of the Coahuila Fold Belt and Sierra Madre Oriental. The tectonic movements reactivated Mesozoic faults (e.g. San Marcos fault) and formed strong asymmetric folds (Sierras La Madera and San Marcos y Pinos). At the end of the Laramide tectonic phase, huge deposits of turbidite sandstones, coming from the emerging areas, terminated the marine sedimentation (McKee et al., 1990; Dickinson \& Lawton, 2001). A magmatic phase, coeval to the compressive tectonics, affected the whole area during the Oligocene. Tectonic distension started about 19 $\mathrm{Ma}$ (Early Miocene) and continued during the Pliocene accompanied by the effusion of calco-alkaline lavas.

Carbonate rocks were progressively uplifted and exhumed by erosion during the late Tertiary. The deeply entrenched valleys, longitudinal and transverse to the main structures, as well as morphological features of 


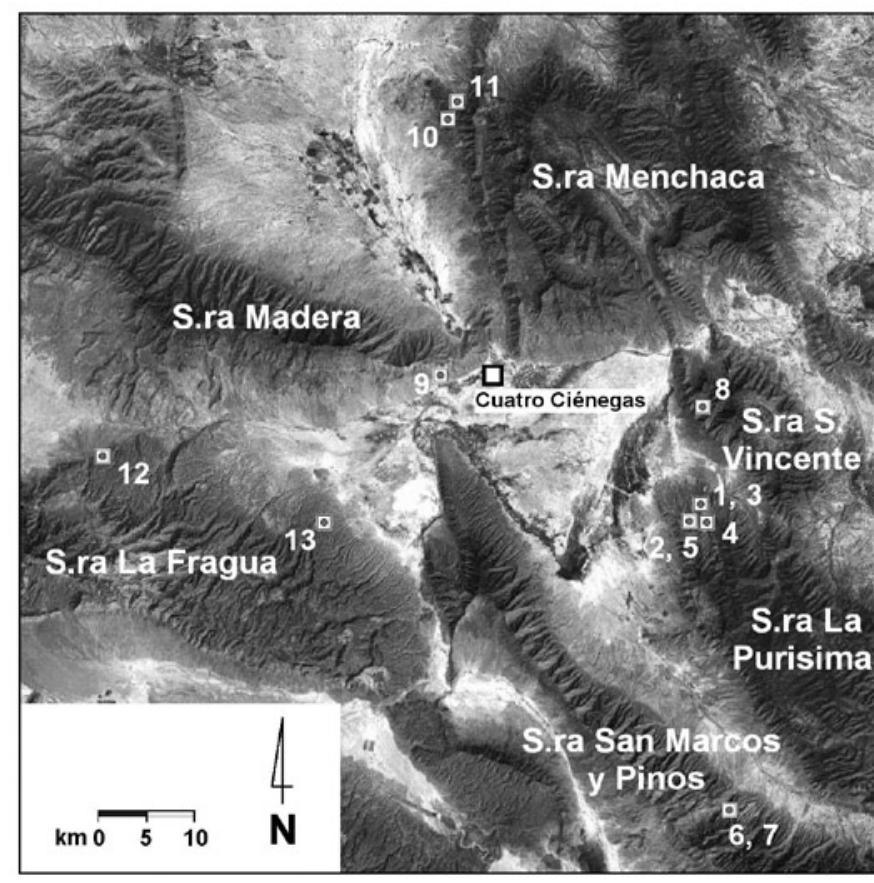

Fig. 2. Satellite image of Cuatro Ciénegas area, which emphasises the structural morphology of sierras, with the location of caves described in the text (cave numbers as in table 1).

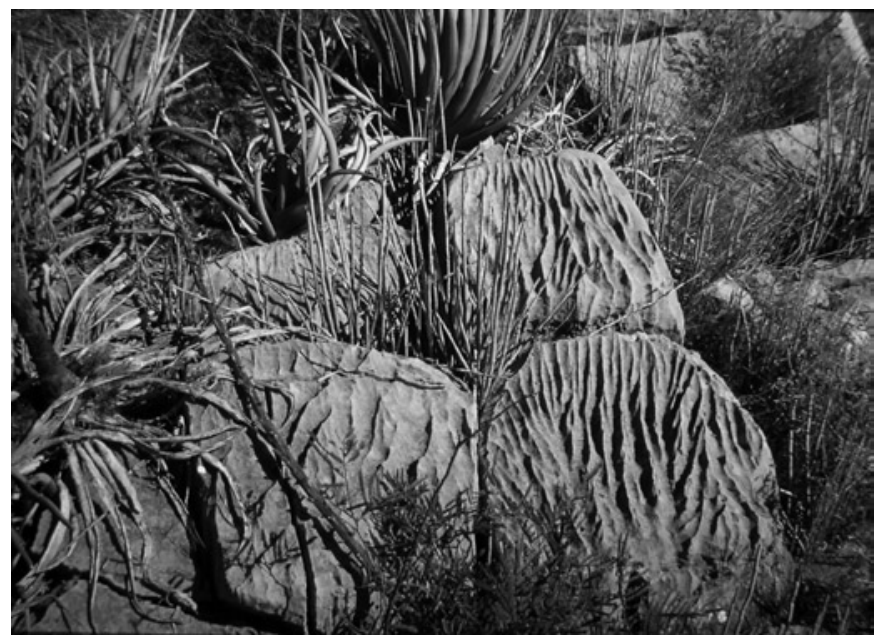

Fig. 3. Solution rills onto bare limestone (photo: Associazione Geografica La Venta).

relict karst on the wall of the canyon, testify to a rapid lowering of the base level, which forced fluvial incision and deactivated endokarst systems.

The relationship between drainage incision and neotectonic evolution is not clear; the last downcutting phases of drainage could have also been the result of a regional and progressive retrograde erosion of major rivers, not necessarily related to tectonic uplift. Nevertheless, the occurrence of travertine deposits, probably due to hydrothermal springs, along the western slope of Sierra San Marcos y Pinos, up to 40-50 $\mathrm{m}$ above the present valley floor suggests neotectonic uplift.

Major canyons display terraces of fluvial sediment, which are probably the results of climatic changes in the late Quaternary, and which confirm a progressive and almost continuous lowering of the regional base level. Undoubtedly, the abrupt climatic changes that affected the Quaternary must have influenced the present landscape of these mountain ridges (Meyer, 1973; Metcalfe et al., 2000).

\section{Hydrology and geochemistry of groundwater}

In the plain of Cuatro Ciénegas, several small lakes, pools and marshes occur in a relatively restricted area (the last inventory reports more than 165 pools). Most of them are located all around the northern part of Sierra San Marcos y Pinos. All the pools are drained by Mezquites river and other artificial channels, whose total discharge is $3,5 \mathrm{~m}^{3} \mathrm{~s}^{-1}$.

Physical and chemical analyses of pool and spring water show a high variability in temperature (19.2 to $\left.33.6^{\circ} \mathrm{C}\right)$, electrical conductivity (543 to $\left.4300 \mu \mathrm{S}\right)$ and salinity (0.2 to $3.8 \mathrm{~g} / \mathrm{L}$ ) (Forti et al., 2003; Johannesson et al., 2004). Temperature and electrical conductivity ranges clearly show the presence of different waters that can be grouped in two categories: "cold" lowsalinity waters and warm high-salinity waters. The formers occur in pedemontane springs and they are fed by local infiltration, usually they have a small discharge. Most of the pools have temperature ranging from 30 to $32{ }^{\circ} \mathrm{C}$, that is to say about $10{ }^{\circ} \mathrm{C}$ upper than local mean temperature of air $\left(22^{\circ} \mathrm{C}\right)$ and thus they are real thermal springs. The results of major elements chemical analysis display two major group of water: sulphate-alkaline earth, deep-flow waters and bicarbonate-alkaline earth, surface waters.

\section{SURFACE KARST}

Dissolution by meteoric water seems to have been limited, at least in terms of the development of surface karst forms. This is due to climatic conditions. The presently rainfall is sparse, ranging from $250 \mathrm{~mm} /$ year in the plain to $400 \mathrm{~mm}$ /year in the higher sierras (Forti et al., 2004a). Even during the wetter climatic phases throughout the second half of the Quaternary (Metcalfe et al., 2000), surface dissolution of limestone must have been relatively minor compared to the physical erosion by streams. As a result, the development of epikarst was retarded. Only in some small areas the surface of bare limestone is modelled by solutional sculpturing (e.g., spitzkarren and rinnenkarren), but these features are not particularly accentuated (Fig. 3).

Because of the persistent physical degradation, it is quite rare to find areas where well-developed solution forms can be observed; they are generally summit areas, near mountain crests, along both the main ridges and secondary drainage divides. The lithologic nature of the bare rock is also crucial: solutional gullies and grooves can originate only on massive limestone that is competent enough to resist physical degradation.

Karst landforms resulting from diffuse or concentrated infiltration are almost entirely absent too. Typical forms of karst landscapes, such as dolines and surface pits, are almost completely missing. Sinkholes formed by the collapse of underground voids are also quite rare. In some cases the few caves opening to the surface as well as rare elongated depressions, which mostly appear in crest areas, originated from 


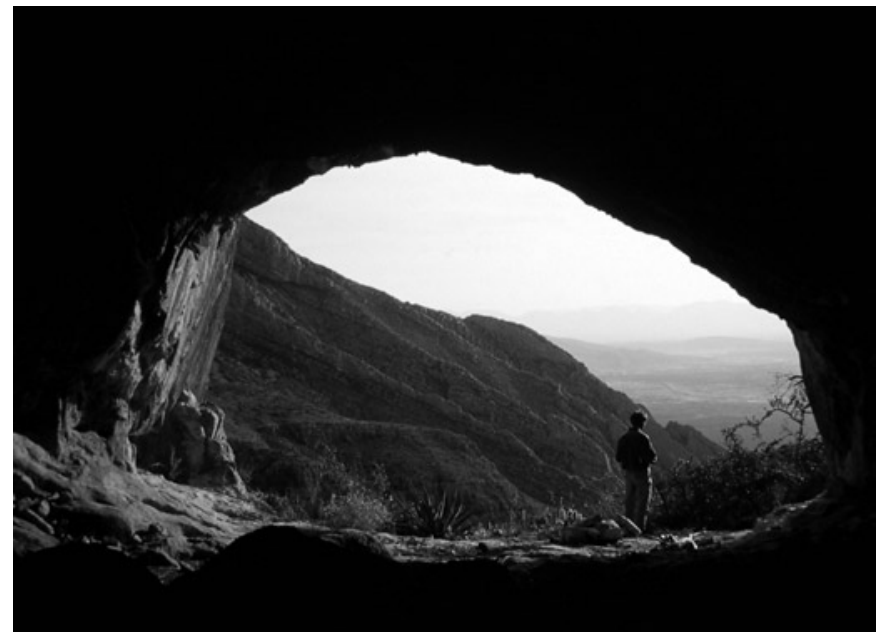

Fig. 4.The entrance of a large cavern enlarged by meteoric weathering along a canyon wall (photo: Ass. Geogr. La Venta)

local gravitational movement along fractures in steep slopes.

Niches and rock shelters are more abundant, especially in the scarps of major canyons. For the most part these features develop along bedding planes or vertical fractures and form circular or elliptical openings (Fig. 4). Although they often resemble phreatic caves intersected by stream erosion, these caves were usually generated by physical weathering, mainly condensation and evaporation with salt precipitation, related to the particular microclimatic conditions of the canyon walls.

\section{SPELEOGENESIS AND MORPHOLOGY OF CAVES}

True solution caves are concentrated in a few restricted areas and are generally small. Only a few caves have a significant length and display features that identify them as segment of ancient cave systems. Most of the caves have a horizontal pattern (see Table 1 for cave dimensions). Solution forms on walls and ceiling, such as solution pockets and cupolas, suggest a slow water flow under bathyphreatic condition, whereas only few marks of a vadose flow can be found. Unfortunately an exhaustive geomorphic analysis of such caves is made difficult by deep degradation of conduit walls, calcite deposits, or guano.

Some of the most important caves in the area of Cuatro Ciénegas are hypogenic, having been formed by rising thermal waters (Forti et al, 2004b). The best example is the Cueva Rancho Guadalupe, in the northeastern part of Sierra la Fragua. This cave has a maze pattern and consists of anastomotic conduits and spherical rooms.

The speleogenetic mechanisms responsible for the long evolution of caves were varied, and each produced a peculiar morphology. These mechanisms may be divided into four main phases, which roughly follow this chronological order:

1) formation isolated, mineralised voids and fissure ("mine caves");

2) formation of hydrothermal caves;

3) origin of meteoric karst (classical karst);

4) development of biogenic solutional forms.
The first two phenomena relate to the deep circulation of fluids, the third to the infiltration of rainwater, and the fourth to the presence of large bat colonies that lived in accessible caves.

\section{Caves associated with mineral deposits}

The most ancient karst phenomena in the area (i.e. paleokarst) are surely those connected with deposits of metallic sulphides (mainly galena and sphalerite, with a significant percentage of silver). The area of Cuatro Ciénegas contains some important ore bodies, which were largely exploited by mining in the past; the largest is that of Mina Reforma (today exhausted) in Sierra La Purísima. In these deposits, sulphides, together with several secondary minerals, among them mainly carbonates, fill the porosity of limestone breccias and hypogenic dissolution voids. The ore deposits are probably diagenetic (Mississippi Valley type) although an influence from volcanic fluids cannot be excluded (Vargas et al., 1993).

Presently, most of these hypogenic cavities are almost completely filled with mineral deposits and can be hardly recognized. Somewhere the filling has not been complete, so that voids can be partially accessed and the original shapes and structures can still be recognized. The average size of such caves is rarely greater than $10 \mathrm{~m}$. Their shapes are irregular and only just controlled by bedding discontinuities. Relevant examples are exposed in several galleries of Mina Reforma. They are irregular voids with walls that are typically covered with crystals of calcite.

The origin of these caves may be related to the circulation of low-temperature thermal solutions enriched by $\mathrm{H}_{2} \mathrm{~S}$, probably during or just after limestone diagenesis (Forti et al., 2006), as proposed for the paleokarst of the Guadalupe Mountains (Hill, 1995), in an environment that persisted from the original limestone platform. According to this hypothesis, the "mine caves" represent an old karst stage, only partially connected to the seepage of meteoric waters, in a Cretaceous carbonate platform. Another possible model is that these caves developed by the upwelling of thermal fluids, which took place during the intense volcanic activity of the Middle Miocene (about 15$10 \mathrm{Ma}$ ). The diffuse circulation of mid-temperature fluids, related to Late Tertiary volcanic activity, is also demonstrated by the occurrence of fluorite veins in the limestone in some places surrounding Cuatro Ciénegas plain (e.g. the northern Sierra San Marcos y Pinos) (Vargas et al., 1993).

\section{Caves of hydrothermal origin}

The most interesting caves in the Cuatro Ciénegas area are those connected with the rising of warm, chemically aggressive waters. Such waters, lacking in heavy metals and low-solubility salts, could have been the final expression of the same process that formed the hypogenic caves associated with ore bodies. The origin of such caves is not connected with the present hydrogeologic and geomorphic setting, and therefore their exposure at the surface appears to be fortuitous, due to the erosion of slopes. 


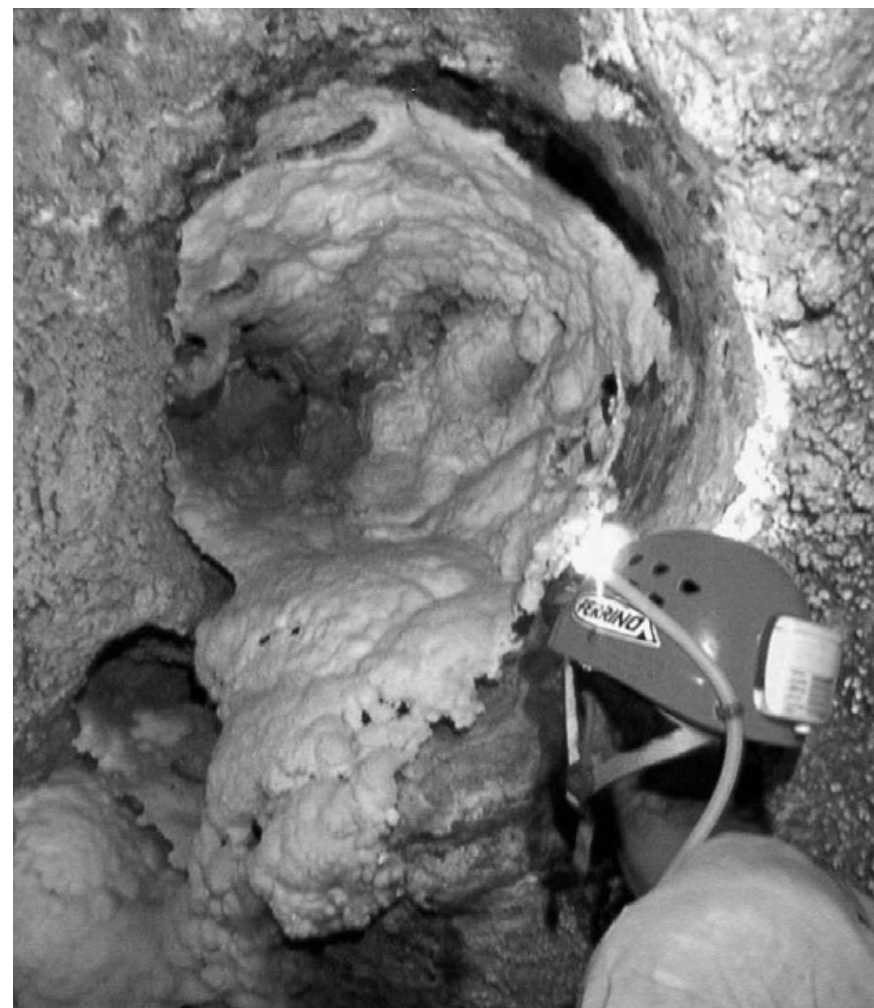

Fig. 5. A wall niche covered with calcite crust. Cueva Rancho Guadalupe (photo Ass. Geogr. La Venta)

One cave in particular, the Cueva Rancho Guadalupe, shows the clearest evidence for a thermal origin. The cave entrance, at the foot of the northern slope of the Sierra La Fragua, is a small pit, perpendicular to the bedding, which leads to a descending gallery about 1.5 $\mathrm{m}$ in diameter with several ceiling domes. It contains the remnants of white crusts (mainly calcite) that once covered the walls. After a few dozen metres the cave divides into several tunnels, with a maze-like pattern that is due to the connection of regular tubes and spherical rooms. Calcite crusts and gypsum crystals cover the walls and the ceiling. The morphology of the solution forms as well as calcite and gypsum deposits are evidences for the circulation of thermal water (Hill \& Forti, 1997; Dublyansky, 2000; Audra et al., 2002). One of the descending conduits leads to a wide tunnel, inclined along the bedding planes, which opens into a large chamber, about 20 x 30 metres wide. Here the dissolving action of thermal waters is evident and has produced hemispherical niches up to $4 \mathrm{~m}$ diameter in the ceiling and walls (Fig. 5). After the excavation phase, the receding thermal waters covered the bedrock surface of this vast room with calcite crusts. Presently, the calcite crusts have mostly fallen from the walls to form a fine granular deposit on the floor. Some calcite dripstones and flowstones post-date the hydrothermal conditions and indicate a phase of carbonate deposition by seepage waters. Today, the cave is generally inactive, but the presence of unaltered concretions testifies to occasional dripwaters, probably fed by local leakage during rainy periods. The cave is interesting also for its mineralogical features, and the analysis of collected samples include many types of minerals, some extremely rare (Forti et al., 2006).

Cueva Rancho Guadalupe is a good sample

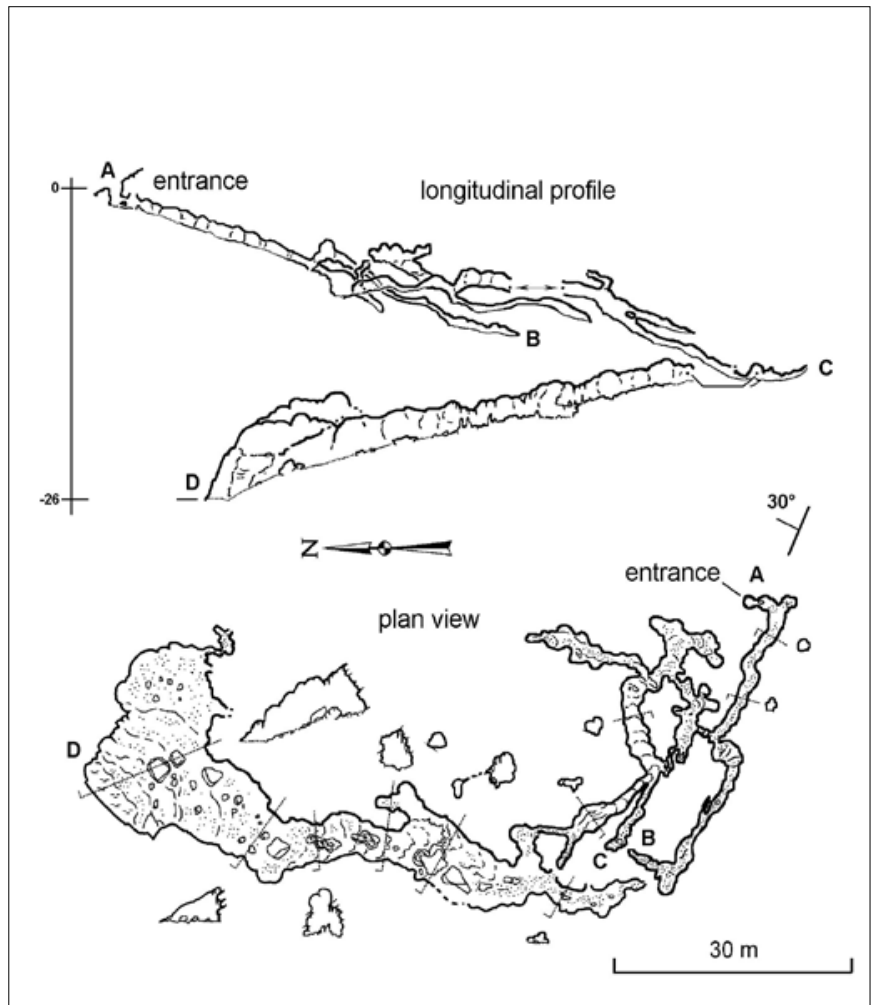

Fig. 6. Plan view and longitidunal profile of Cueva Rancho Guadalupe (cave survey: Ass. Geogr. La Venta)

of a monogenic hydrothermal cave (Forti, 1996; Dublyansky, 2000), the structure of which consists typically of a large basal chamber from which secondary conduits and tunnels depart upwards (Fig. 6). This pattern is rare throughout the world and has been described in detail almost exclusively in the area of Budapest (Dublyansky, 1995). In this kind of cave, the ascending water velocity is very low and the aggressiveness of the water not very strong. The rate of dissolutional rock removal is limited, and small to medium-sized caves are the typical result. In these hydrodynamic conditions the shape of a cave depends on: the mode of ingress of thermal waters into the rock, the type of convective movement, the velocity of rising thermal water and the structural conditions of the rock (Bakalowicz et al., 1987, Dublyansky, 1995). Caves like Rancho Guadalupe can be generated only if the thermal water intrusion is quite concentrated. It is also necessary for the original rock to have thick and sparsely fractured layers.

The genesis of Rancho Guadalupe cave seems to have been similar to those of the Budapest karst (Dublyansky, 1995). The rising of thermal waters induces the development of large hydrothermal chambers in which the water accumulates (Fig. 7-1). Convective motion develops the upward formation of a ramiform series of coalescent sub-spherical voids (Fig. 7-2). When the cave becomes partially dewatered due to the lowering of local hydrologic base level, the loss of $\mathrm{CO}_{2}$ to the atmosphere allows the development of some shallow phreatic speleothems such as wall crusts and sedimentation of calcite rafts on the cave floor from overlying free water surfaces (Fig. 7-3). At the same time the seepage of meteoric water begins the normal calcite deposition in the unsaturated 
zone. Gradual erosion connects the cave to the land surface and the thermal waters then abandon the cave (Fig. 7-4). All the thermal forms and deposits are thus deactivated, and meteoric seeping waters form typical vadose speleothems such as dripstone and flowstone.

In the Cuatro Ciénegas area we have identified some other caves that were formed by thermal waters: Cueva del Junco, also in Sierra La Fragua, and Cueva Tanque Nuevo, in Sierra San Marcos y Pinos, are two other relevant examples, although not yet studied. Hydrothermal processes could also have been important in the formation of Cueva Hundida and Cueva la Leona in Sierra Menchaca. Probably a large number of hydrothermal caves still lie underground with no connection to the surface, and others may have been destroyed by surface erosion.

\section{Caves of meteoric origin}

Most of the caves we surveyed were formed by meteoric waters and show a horizontal development. In many cases their size decreases rapidly from the entrance inwards, and they seem to be small interstratal conduits enlarged by gradual weathering that has proceeded from the entrance. Some of these caves could be remnants of ancient karst conduits and in places we have observed dissolutional forms in the walls that resemble solution niches formed under phreatic conditions (Palmer, 1991). Unfortunately the state of alteration and decay in most of these caves does not allow us to draw a reliable hypothesis about their origin.

In the Sierra La Purisima and particularly in Canyon El Pedregoso, we found relics of phreatic caves that were apparently formed by circulation of cold meteoric

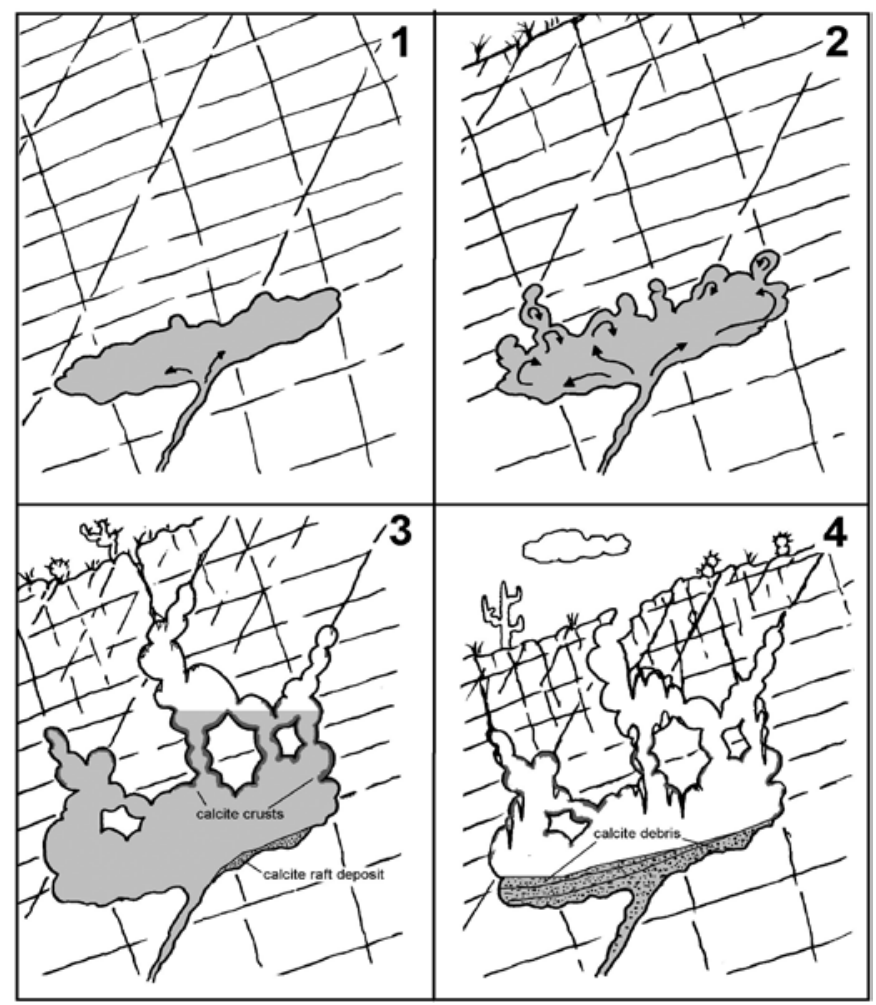

Fig. 7. Evolution sketch of Rancho Guadalupe cave (from Forti et al., 2004b, modified: see text for details). waters. The canyon, which trends northward, shows in its last 7-8 $\mathrm{km}$ very steep slopes where several cave entrances are visible at varied altitudes. Speleological researches focused on a portion of the canyon about $4 \mathrm{~km}$ long, where many caves were evident. The systematic exploration of all accessible caves allowed us to describe their main morphological features (Forti et al., 2004b).

At present, the caves in the upper walls may be entered only for some dozen metres (the longest, Cueva Murciélago, has $130 \mathrm{~m}$ of development). Here the cave passages show a rounded cross section and were mostly formed under water-filled conditions. They originated along favourable bedding-plane partings or intersections between bedding and variously oriented fractures (Fig. 8). Most probably this network of tubes developed in an aquifer confined by the overlying marly cover. This process took place in an early phase of essentially laminar flow that produced the net of phreatic tubes that can be recognized today at various altitudes. This upper level of relict tunnels does not show traces of vadose downcutting, which means that they must have developed before the incision of the canyon, when limestone was locally still capped by marly formations.

The longest caves (e.g. Cueva El Pedregoso, length $380 \mathrm{~m}$; Cueva las Guaitas, length $220 \mathrm{~m}$ ) conversely lie at the bases of the walls along a horizon marked by a lithologic change from pure limestone to underlying marly and less karstifiable beds (Fig. 9). This might have favoured the formation of caves on the contact on one hand, and the persisting of the water flow also after the canyon cutting. They also consist mainly of regular tubes showing rounded cross sections due to water flowing under pressure and are developed

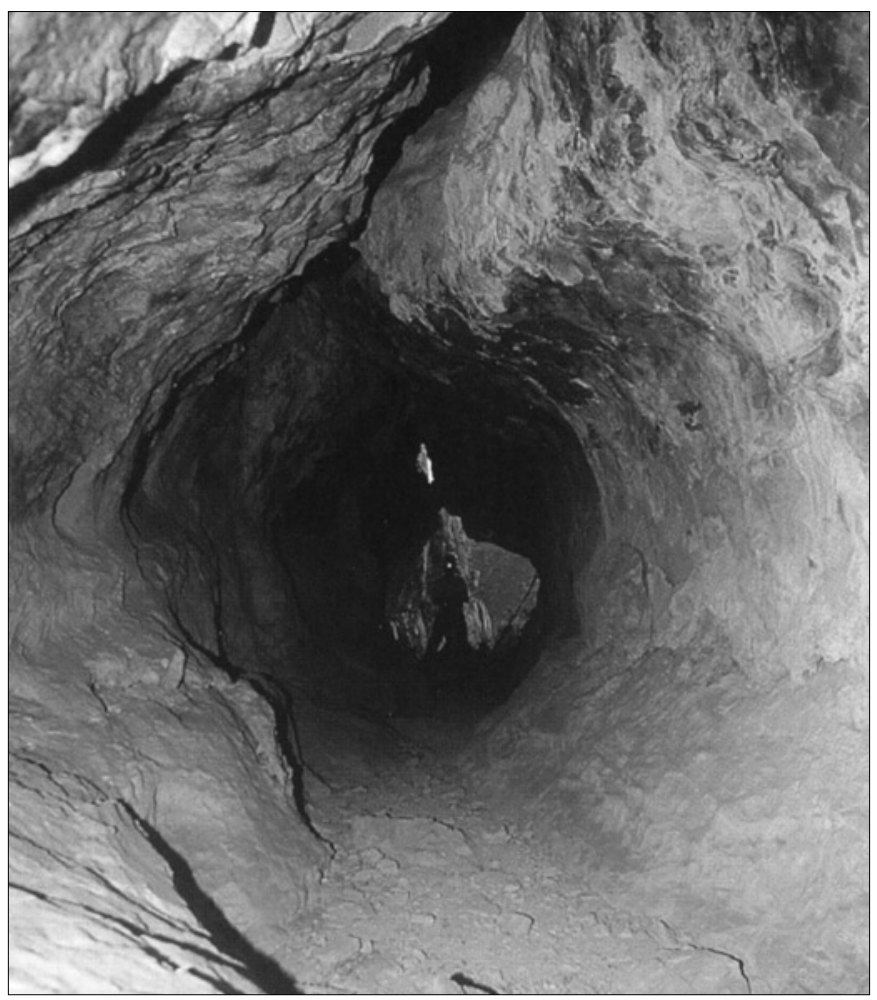

Fig. 8. A typical passage of the upper level of relict phreatic caves in the Canyon el Pedregoso (photo: Ass. Geogr. La Venta) 


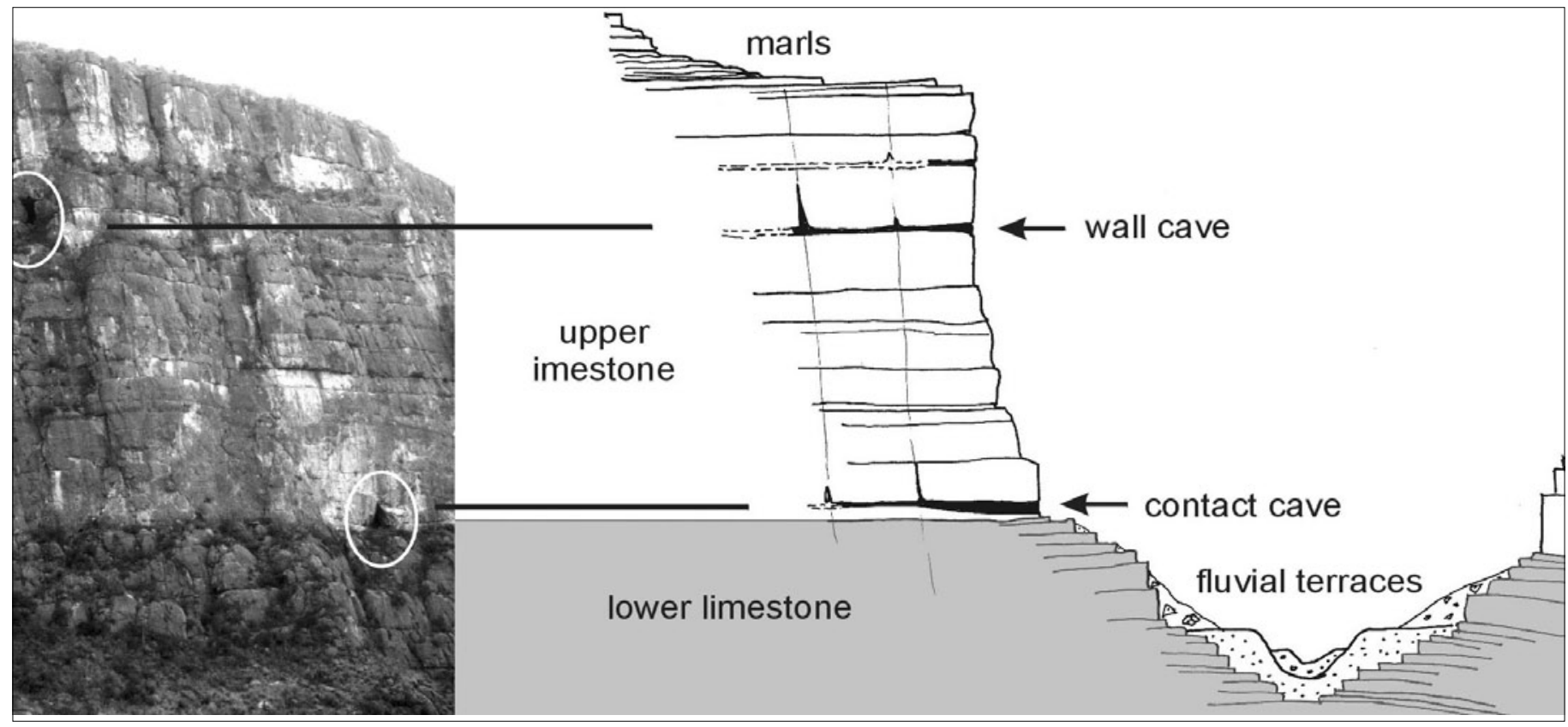

Fig. 9. Structural positions of caves in the Pedregoso Canyon.

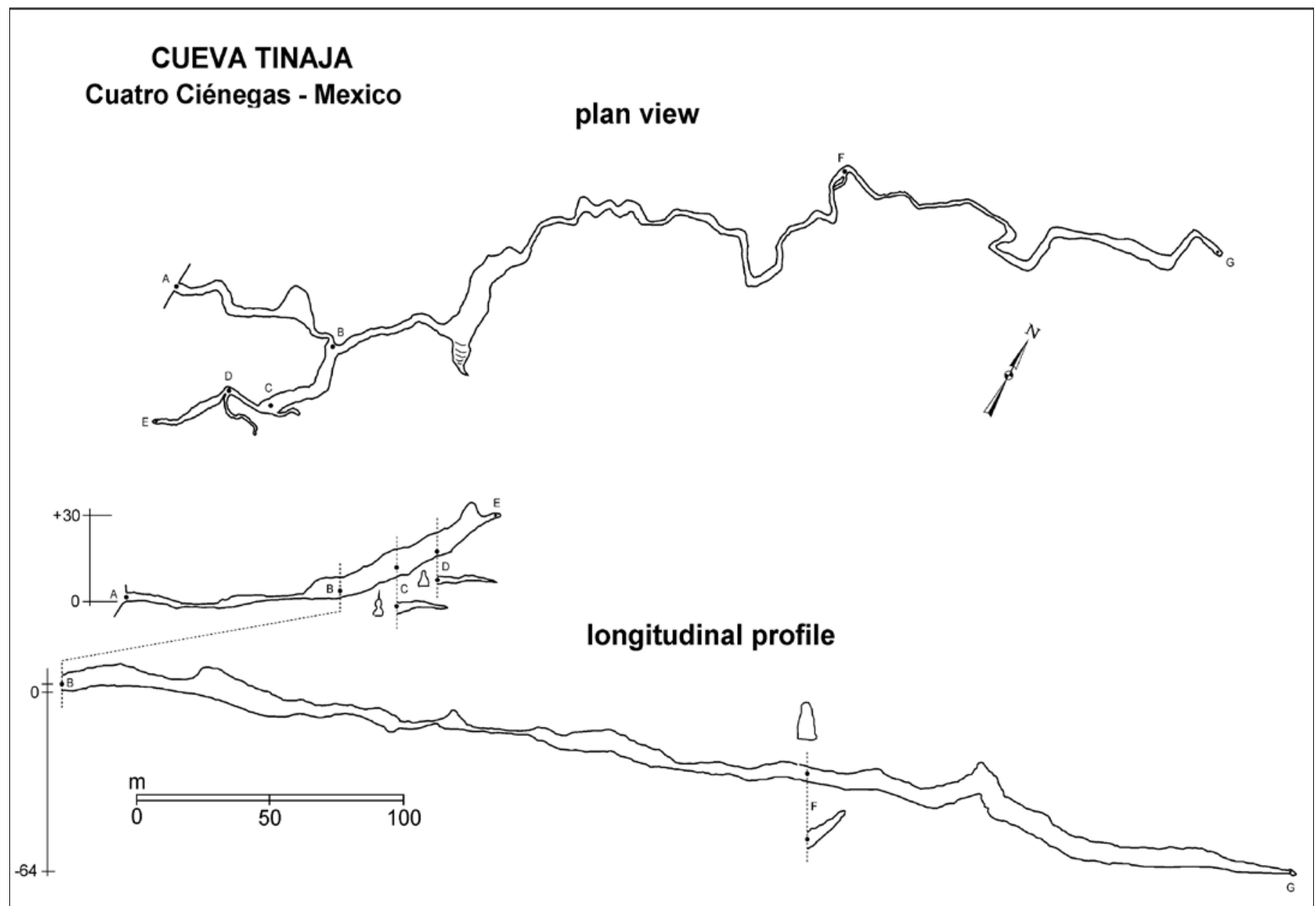

Fig. 10. Plan view and longitudinal profile of Cueva Tinaja (Pedregoso Canyon, Sierra la Purisima) (Cave survey: Ass. Geogr. La Venta).

along stratal discontinuities. Vadose forms are present only in some passages and originated when canyon deepening intersected these caves. Some of the entrances of the lower caves show unmistakable channels cut into the rocky slopes down to the canyon bed, which indicates the occasional activity of vadose springs.

The longest and deepest cave of Pedregoso Canyon is Cueva Tinaja (Fig. 10). It is $670 \mathrm{~m}$ long, with a vertical range of $98 \mathrm{~m}$. It was mined for guano in the past and consists of a gallery that gently descends toward the northeast. Also for this cave we suggest a predominantly phreatic origin, from waters circulating upward along bedding-plane partings.

Two caves in Sierra San Marcos y Pinos, Cuevas Rosillo 1 and Rosillo 2, are also meteoric in origin. 


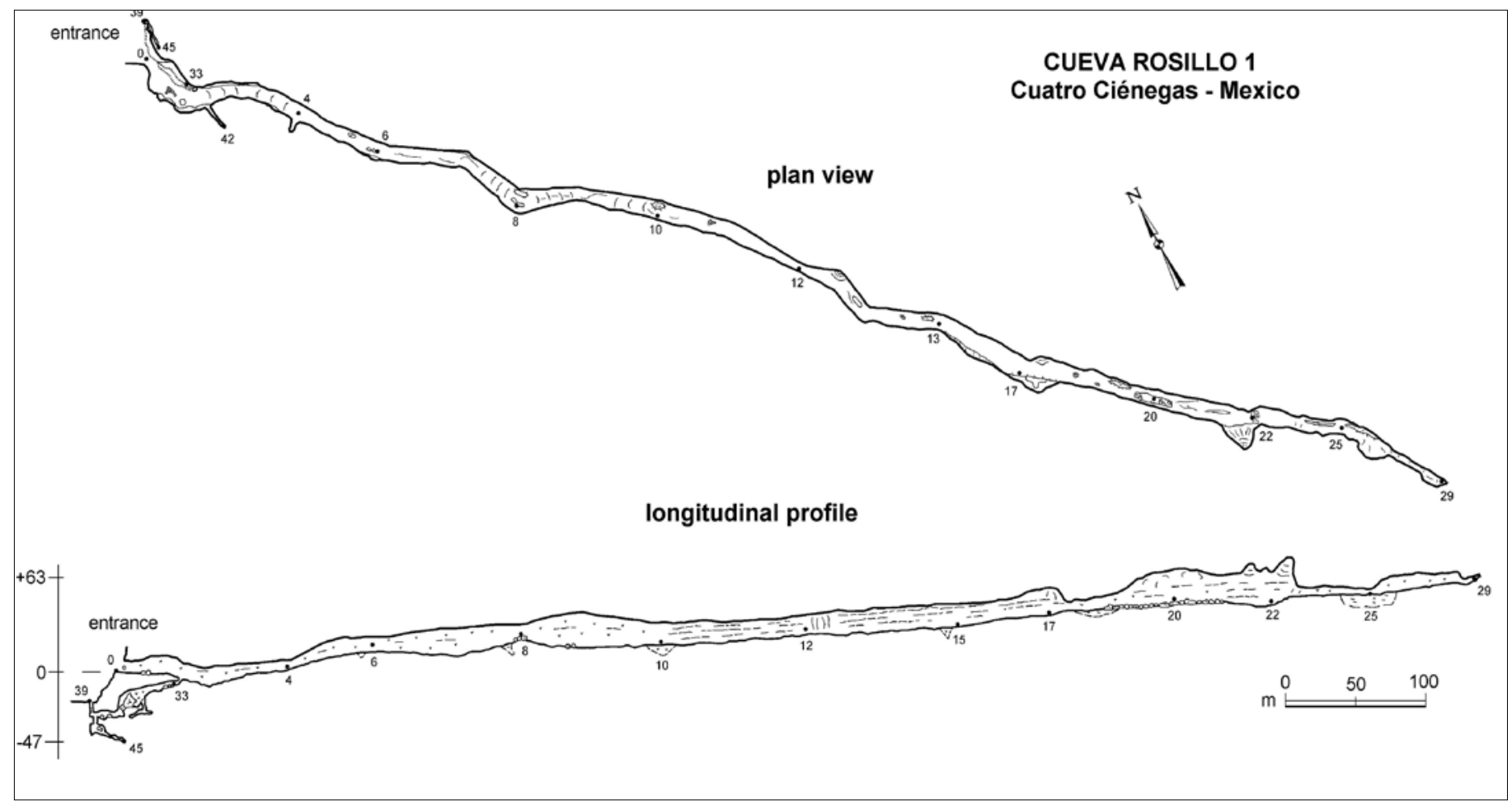

Fig. 11. Plan view and longitudinal profile of Cueva EI Rosillo 1 (Sierra San Marcos y Pinos) (cave survey: Ass. Geogr. La Venta).

The first consists of a gallery $930 \mathrm{~m}$ long with quite constant dimensions throughout its entire length. This long tunnel, roughly quadrangular in cross section, has an average width of $10 \mathrm{~m}$ and a height ranging from 6 to $20 \mathrm{~m}$. Its passage pattern is rectilinear, with a NW$\mathrm{SE}$ orientation. Its size decreases toward the end as the ceiling lowers and the floor rises because of detritus and calcite flowstone (Fig. 11). The flowstone is deeply altered by organic acids of biogenic origin. The whole gallery contains domes and rounded lateral niches (Fig. 12), some of which are the result of corrosion by guano deposits. The walls are engraved by scallops averaging 1-2 metres long, which indicate a very slow water flow. Cueva del Rosillo 2 opens just opposite Rosillo 1 and shows similar features but a shorter length.

These caves are no doubt two segments of the same conduit, separated by the incision of the valley. Their great sizes suggest they are a segment of an ancient and significant collector that drained the waters from a large area of Sierra San Marcos y Pinos in the NW direction. Their original phreatic shape has been modified by vadose flow in the opposite direction, which widened the gallery, incised a floor canyon, and partially filled the cave with a variety of deposits.

After deactivation due to lowering of base level, the caves were exposed to the surface and apparently hosted a great colony of bats. The occurrence in the ceiling of deeply eroded calcite deposits suggests a second phase of water invasion, which probably allowed the chemical reaction between limestone or calcite deposits and organic acids, to form a thick crust of phosphorite on the cave floor, which has been almost completely removed through the mining activity.

Other relict phreatic caves occur in Sierra San Vincente (Cueva de los Murcielagos, length $102 \mathrm{~m}$ ) and Sierra Madera (Cueva del Guano, length $402 \mathrm{~m}$ ).

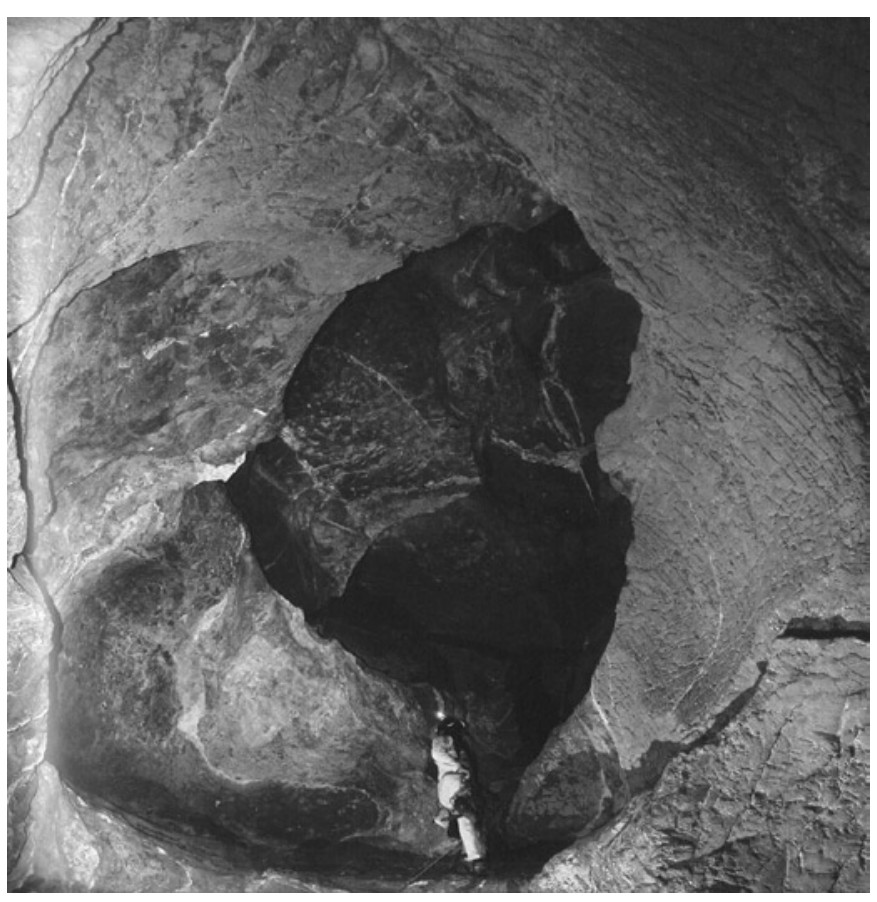

Fig. 12. A large solutional cupola on the ceiling of Cueva Rosillo 1 (photo: Ass. Geogr. La Venta)

In all cases, the caves show evidence for an ancient deep karstification, which occurred before the phases of intense superficial erosion and of downcutting of the canyon system. This could explain the relatively small number of known caves and the limited development of most, as well as the fact that they are mostly obstructed by deposits of calcite beyond a few tens of metres.

\section{Biogenic forms connected with guano}

At the present time, the most active speleogenetic processes are associated with significant guano deposits. Some caves, after being cut by surface 


\begin{tabular}{|c|c|c|c|c|c|c|c|c|}
\hline $\mathbf{n .}$ & Cave & Zone & Fuse & $\begin{array}{c}\text { UTM E } \\
\text { (NAD27) }\end{array}$ & $\begin{array}{c}\text { UTM N } \\
\text { (NADS27) }\end{array}$ & $\begin{array}{c}\text { elevation } \\
\mathbf{m} \text { a.s.I. }\end{array}$ & $\begin{array}{c}\text { length } \\
\mathbf{m}\end{array}$ & \begin{tabular}{c} 
depth $\mathbf{m}$ \\
\hline 1
\end{tabular} \\
\hline 2 & Cueva Tinaja & La Purisima & 14 & 219648 & 2970619 & 1020 & 670 & $+30,-64$ \\
\hline 3 & Cueva el Triangulo & La Purisima & 14 & 219036 & 2970092 & 1130 & 55 & +4 \\
\hline 4 & Cueva el Murcielago & La Purisima & 14 & 219085 & 2970132 & 1170 & 132 & +5 \\
\hline 5 & Cueva las Guaitas & La Purisima & 14 & 218545 & 2969308 & 1140 & 220 & +13 \\
\hline 6 & Cueva el Pedregoso & La Purisima & 14 & 218814 & 2967935 & 1160 & 381 & -8 \\
\hline 7 & Cueva Rosillo 1 & S. Marcos Y Pinos & 14 & 220497 & 2936552 & 1360 & 1110 & $+53,-47$ \\
\hline 8 & Cueva Rosillo 2 & S. Marcos Y Pinos & 14 & 220519 & 2936754 & 1400 & 223 & $+5,-12$ \\
\hline 9 & Cueva de los Murciélagos & San Vincente & 14 & 216561 & 2984987 & 1030 & 120 & +20 \\
\hline 10 & Cueva del Guano di Don Beto & Madera & 13 & 784740 & 2987267 & 976 & 402 & $+31,-26$ \\
\hline 11 & Cueva la Leona & Menchaca & 13 & 784202 & 3017873 & 1253 & 464 & +35 \\
\hline 12 & Cueva Hundida & Menchaca & 13 & 784234 & 3018462 & 1253 & 854 & -122 \\
\hline 13 & Cueva Rancho Guadalupe & La Fragua & 13 & 745782 & 2977148 & 1280 & 190 & -26 \\
\hline
\end{tabular}

Table 1. Caves surveyed during La Venta expeditions at Cuatro Ciénegas (numbers as in Fig. 2).

erosion, have been occupied by big bat colonies, probably for many thousands of years, during which a large amount of guano accumulated. The presence of guano allowed these caves to undergo a further significant development even without significant water flows. Besides being exothermic and producing convective air flows in the cave atmosphere, the transformation and mineralization of guano also causes a series of chemical reactions which, on one hand, develop a large quantity of carbon dioxide and steam, and on the other hand, help to form a number of strong acids, mainly nitric acid $\left(\mathrm{HNO}_{3}\right)$, sulphuric acid $\left(\mathrm{H}_{2} \mathrm{SO}_{4}\right)$ and phosphoric acid $\left(\mathrm{H}_{3} \mathrm{PO}_{4}\right)$.

The morphological consequence of this process can be noteworthy, as it enables the formation of large concave structures in outward-jutting walls (lateral niches), domes due to condensation corrosion of the ceiling, and gullies and corrosion holes in the floor. Condensation waters enriched with organic and inorganic salts can then generate speleothems, both as concretions and as absolutely peculiar organic minerals (Forti et al., 2006). Somewhere, biogenic corrosional forms can completely alter or disguise the original shapes of caves.

\section{CONCLUSIONS}

Despite the fact that the mountains around Cuatro Ciénegas consist mainly of carbonate rock, surface karst landforms are quite rare because of the predominance of intense physical weathering. Significant karst landforms occur only in small areas and are generally located along major mountain crests. Typical infiltration forms, such as dolines, are almost entirely absent.

Endokarst features seem also to be concentrated in restricted areas. Presently no large cave systems are known. Among several reasons, one is surely the limited exploration of this vast territory, which is partly due to the inaccessibility of the higher ridges. About fifty caves are known at the moment, mostly of small size.

In our opinion, however, certain objective factors may be responsible for the limited karst development. We consider these to be related to the morphological and climatic dynamics of this area in the recent geological past. The environmental conditions, which probably distinguished this area in the last million years, must have limited the karst processes because the relief was sculpted by intense physical degradation. This is proved by the dense network of canyons and minor channels in the mountain slopes and by the significant fluvial deposits, originally mainly alluvial fans, which have filled the intra-mountain plains.

Surface and deep karst processes could not compete with surface erosion. Karst could hardly develop except in some local and particularly favourable situations, or thanks to peculiar processes. All our research in the explored caves proved how underground karst phenomena are mainly the result of particular paleohydrologic conditions related to the circulation of thermal waters or deep-seated flow.

According to present knowledge, caves in Cuatro Ciénegas include various types and situations related to diverse genetic processes, which involve complex speleogenesis throughout hypogenic and meteoric karst processes over a long period, probably of several million years.

The mineral deposits of mixed sulphides, which supplied uncommon metal elements, surely influenced the karst phenomena in the course of their earliest development. Later, thermal water circulation created chemical and physical conditions that resulted in peculiar minerals and crystal forms.

The diffuse circulation of thermal waters could be 
related to Late Tertiary volcanic activity and is also demonstrated by the occurrence of fluorite veins, due to mid-temperature fluids, in several places all around the Cuatro Ciénegas plain and of travertine deposits, whose top surfaces are up to 40-50 m above the present base level.

Caves originated by meteoric waters are also present but they can be accessed only were erosion has deeply cut the mountain ridges. Morphological features suggest bathy-phreatic conditions for the most part of their development, with only some local vadose entrenchment during the latest active phases.

In the more recent past, some of these caves hosted great colonies of bats, which produced guano deposits several meters thick. Inside these deposits, microbiological reactions produced a large and exceptional variety of minerals, phosphatic for the most part.

\section{ACKNOWLEDGMENTS}

The authors are grateful to Área de Protección de Flora y Fauna Cuatro Ciénegas, Instituto Coahuilense de Ecologia, Semarnap, Conabio and Pronatura Noreste A.C., for their permission to field research. We are also indebted to all the participants to "Cuatro Ciénegas" Project for their help in the field and logistic support.

Finally, we sincerely thank Jo De Waele and Peggy Palmer, for the useful suggestions, and Philippe Audra and Art Palmer for the revision of the manuscript.

\section{REFERENCES}

Audra P., Bigot J. Y. \& Mocochain L., 2002 - Hypogenic caves in Provence (France): Specific features and sediments. Acta Carsologica, 31(3): 33-50.

Bakalowicz M.J., Ford D.C., Miller T.E., Palmer A.N. \& Palmer M.V., 1987 - Thermal dissolution caves in the Black Hills, South Dakota. Geological Society of America Bulletin, 99: 729-738.

Bernabei T., Giulivo I., Mecchia M. \& Piccini L., 2002 Carsismo e mistero delle acque nel deserto: il progetto Cuatro Ciénegas, nello stato messicano di Coahuila. Speleologia, 46: 50-65.

Dickinson W.R. \& Lawton T.F., 2001 - Carboniferous to Cretaceous assembly and fragmentation of Mexico. Geological Society of America Bulletin, 113: 11421160.

Dublyansky Y. V., 1995 - Speleogenetic history of the Hungarian hydrothermal karst. Environmental Geology, 25: 24-35.

Dublyansky Y. V., 2000 - Hydrothermal speleogenesis: its setting and peculiar features. In: Klimchouk A. B., Ford D. C., Palmer A. N., Dreybrodt W., (eds.) "Speleogenesis and evolution of karst acquifers", National Speleological Society, Huntsville: 292-297.

Forti P., 1996 - Thermal Karst Systems. Acta Carsologica, 25: $99-117$.

Forti P., Giulivo I., Piccini L. \& Tedeschi R. (2003) The karst aquifer feeding the Cuatro Ciènegas pools (Coahuila, Mexico): its vulnerability and safeguard. Proc. "Aquifer Vulnerability and Risk", Salamanca, Mexico, vol. 2 287-299.
Forti P., Giulivo I., Mecchia M. \& Piccini L. (2004a) - The physical environment: geography and climate of Cuatro Ciénegas. In: Badino G., Bernabei T., De Vivo A., Giulivo I., Savino G. (eds.) "Under the Desert: the mysterious waters of Cuatro Ciénegas". Edizioni Tintoretto, Treviso: 28-34.

Forti P., Giulivo I., Mecchia M. \& Piccini L. (2004b) - The karst of Cuatro Ciénegas; In: Badino G., Bernabei T., De Vivo A., Giulivo I., Savino G. (eds.) "Under the Desert: the mysterious waters of Cuatro Ciénegas". Edizioni Tintoretto, Treviso: 186-200.

Forti P., Galli E. \& Rossi A. (2006) - Peculiar minerogenetic cave environments of Mexico: the Cuatro Ciénegas area. Acta Carsologica, 35/2: 79-98.

Grall G., 1995 - Cuatro Ciénegas: Mexico's Desert Aquarium. National Geographic Magazine, October 1995: 84-97.

Hill C., 1995 - Sulfur redox reactions: Hydrocarbons, native sulfur, Mississippi Valley-type deposits, and sulfuric acid karst in the Delaware Basin, New Mexico and Texas. Environmental Geology, 25: 16-23.

Hill C. \& Forti P., 1997 - Cave minerals of the World. National Speleological Society, Huntsville: 464 pp.

Johannesson K. H., Corte's A. \& Kilroy K. C., 2004 Reconnaissance isotopic and hydrochemical study of Cuatro Ciénegas groundwater, Coahuila, Mexico. Journal of South American Earth Sciences, 17: 171180.

Lehmann C., Osleger D.A. \& Montañez I.P., 1998 Controls on cyclostratigraphy of Lower Cretaceous carbonates and evaporites, Cupido and Coahuila platforms, northeastern Mexico. Journal of Sedimentary Research, 68: 1109-1130.

Lehmann C., Osleger D.A. \& Montañez I.P., Sliter W., Arnaud-Vanneau A., Banner J., 1999 - Evolution of Cupido and Coahuila carbonate platforms, Early Cretaceous, North-eastern Mexico. Geological Society of America Bulletin, 111: 1010-1029.

MC Kee J.W., Jones N.W. \& Long L.E., 1990 - Stratigraphy and provenance of strata along the San Marcos fault, central Coahuila, Mexico. Geological Society of America Bulletin, 102: 593-614.

Metcalfe S.E., Bimpson A., Courtice A.J., O'Hara S.L. \& Taylor D.M., 1997 - Climate change at the monsoon/ westerly boundary in northern Mexico. Journal of Paleolimnology, 17: 155-171.

Metcalfe S.E., O'Hara S.L., Caballero M. \& Davies S.J., 2000 - Records of Late Pleistocene-Holocene climatic change in Mexico. Quaternary Science Reviews, 19: 699-721.

Meyer E.R., 1973 - Late-Quaternary paleoecology of the Cuatro Ciénegas basin, Coahuila, Mexico. Ecology, 54: 982-985.

Palmer A. N., 1991 - The origin and morphology of limestone caves. Geological Society of America Bulletin, 103: $1-21$.

Vargas J. C., Duràn Miramontes H. A., Sànchez Silva E., Arias Gutiérrez M. A. \& Parga Pérez J. J., 1993 Monografia geologico-minera del estado de Coahuila. Secretaria de Energia, Minas e Industria Paraestatal, Subsecretaria de Mines, Mexico, publicaciòn M-9e, 154 pp. 